Transactions of the Karelian Research Centre of the Russian Academy of Sciences

No. 3. 2019. P. 28-33

DOI: 10.17076/lim989
Труды Карельского научного центра РАН

№ 3. 2019. C. 28-33

УДК 551.482.213+528.8.04

\title{
ATMOSPHERIC COLUMNAR CO 2 ENHANCEMENT OVER E. HUXLEYI BLOOMS: CASE STUDIES IN THE NORTH ATLANTIC AND ARCTIC WATERS
}

\author{
E. A. Morozov, D. V. Kondrik, S. S. Chepikova, D. V. Pozdnyakov
}

Nansen International Environmental and Remote Sensing Centre, St. Petersburg, Russia

\begin{abstract}
Blooms of a coccolithophore E. huxleyi are generally huge, occur annually and in the oceans of both Hemispheres. As a calcifying algal species, E. huxleyi is known to enhance the partial pressure of dissolved $\mathrm{CO}_{2}$ in the surface ocean, thus reducing its ability to absorb atmospheric $\mathrm{CO}_{2}$. Here we report on the results of our satellite study of $\mathrm{CO}_{2}$ enhancement in the atmospheric column over $E$. huxleyi blooms in the North, Greenland, Iceland and Barents seas. The study is based on OCO-2 and wind force and direction data, and $E$. huxleyi bloom masks developed by us earlier. Eight case studies are discussed herein relating to the time period 2015-2018. The results obtained are strongly indicative that, indeed, the phenomenon of $E$. huxleyi blooms noticeably affects the carbon fluxes between the atmosphere and the surface ocean: the quantified enhancement of $\mathrm{CO}_{2}$ content in the atmospheric column over the bloom area in five out of eight case studies proved to be in the range of $0.6-3.0 \mathrm{ppm}$. It is also shown that the magnitude of $\mathrm{CO}_{2}$ enhancement in the atmospheric column is significantly controlled by air advection in the boundary layer.
\end{abstract}

Ke yw ord s: satellite remote sensing; OCO-2 data; enhancement of atmospheric columnar $\mathrm{CO}_{2}$ content over E. huxleyi blooms in Subarctic and Arctic seas; Emiliania huxleyi; wind and atmospheric advection.

\section{Е. А. Морозов, Д. В. Кондрик, С. С. Чепикова, Д. В. Поздняков. УВЕЛИЧЕНИЕ КОНЦЕНТРАЦИИ СО 2 В АТМОСФЕРНОМ СТОЛБЕ НАД ОБЛАСТЬЮ ЦВЕТЕНИЯ Е. НUXLEYI: КОНКРЕТНЫЕ СЛУЧАИ В ВОДАХ СЕВЕРНОЙ АТЛАНТИКИ И АРКТИКИ}

В этой краткой статье сообщается о результатах спутниковых исследований по увеличению содержания $\mathrm{CO}_{2}$ в атмосферном столбе над цветениями E. huxleyi в Северном, Гренландском, Исландском и Баренцевом морях. Исследование базируется на данных космической станции ОСО-2 по содержанию $\mathrm{CO}_{2}$ в атмосферном столбе, на спутниковых данных о силе и направлении приводного ветра, с использованием ранее нами разработанных масок цветений E. huxleyi. Всего было выявлено и исследовано восемь конкретных случаев за период с 2015 по 2018 гг., когда траектория пролета станции ОСО-2 пролегала по области цветения и выходила за ее пределы, что позволяло оценивать влияние цветения E. huxleyi на содержание $\mathrm{CO}_{2}$ в атмосферном столбе. Полученные результаты однозначно свидетельствуют о влиянии исследуемого явления на потоки углерода на границе раздела «атмосфера-океан». В пяти случаях из восьми увеличение $\mathrm{CO}_{2}$ в атмосферном столбе над областью цветения $E$. huxleyi оказывалось в диапазоне 0,6-3,0 ppm. Выяснено, что 
конкретная величина увеличения в некоторых случаях существенно зависит от адвекции воздушных масс в приграничном слое.

Ключе в ы е с ло в а: спутниковое дистанционное зондирование; данные ОСО-2; увеличение концентрации $\mathrm{CO}_{2}$ в атмосферном столбе над цветениями E. huxleyi в морях субарктической Атлантики и Арктики; Emiliania huxleyi; ветер и адвекция воздушных масс.

\section{Introduction}

Among marine biosystems, coccolithophores (class Prymnesiophycea) are the most productive calcite-producing organisms in the world's oceans [Thierstein, Young, 2013]. Dissolved carbon dioxide of atmospheric origin interacts with dissolved calcite with the formation of $\mathrm{HCO}_{3}^{-}$and $\mathrm{Ca}^{+2}$. Thus, any increase in the partial pressure of atmospheric $\mathrm{CO}_{2}$ leads to a shift between the marine suspended organic and inorganic carbon. This, in turn, is bound to affect the carbon cycle in the atmosphere - ocean surface balance.

In addition to the production of particulate calcite, coccolithophores are capable of increasing dissolved $\mathrm{CO}_{2}$ partial pressure within their blooming areas [Holligan et al., 1993; Kondrik et al., 2018].

Conjointly, these two mechanisms affect the carbon balance in surface ocean and tend to weaken marine carbon sinks, which has farreaching consequences in terms of planetary climate change [IPCC, 2014].

Within the coccolithophore group, E. huxleyi is the most widespread species in the world's oceans [Westbroek et al., 1985; Moore et al., 2012]. It forms gigantic blooms with a surface of several thousand square kilometers [Kondrik et al., 2017], but sometimes exceeding one million square kilometers [Balch et al., 2014].

The aforementioned E. huxleyi bloom-driven enhancement of dissolved $\mathrm{CO}_{2}$ partial pressure can reduce, nullify or even reverse the flux of $\mathrm{CO}_{2}$ at the atmosphere-ocean interface. Indeed, Shutler et al. [2013] report on an average reduction in the monthly air-sea $\mathrm{CO}_{2}$ flux by about $55 \%$ across the marine tracts encompassing extensive E. huxleyi blooms in the North Atlantic, whereas the maximum reduction over the time period 1998-2007 was registered at $155 \%$.

Here we present our results on several case studies in the North, Iceland, Greenland and Barents seas. The study was designed to quantify the atmospheric columnar $\mathrm{CO}_{2}$ over $E$. huxleyi blooms based on remote sensing data from the Orbiting Carbon Observatory OCO-2 that was put into orbit in 2014 to study $\mathrm{CO}_{2}$ concentration and spatio-temporal distribution in the Earth's atmosphere
[Crisp, 2015]. The areas targeted in the above seas were identified in advance making use of $E$. huxleyi bloom masks developed on the basis of ocean color data from the ocean-colour climate-change initiative $\mathrm{OC} \mathrm{CCl}$ data archive [Sathyendranath, Krasermann, 2014].

\section{Methodology}

Previously, based on the developed bloom masking technology, i. e. the methodology of $E$. huxleyi bloom detection and contouring, the 1998-2018 time series of blooms of this alga were obtained for the Subarctic Atlantic and Arctic Seas [Kondrik et al., 2019; Selyuzhenok et al., 2019]. For the revealed locations of $E$. huxleyi blooms, the 2015-2018 OCO-2 data were subjected to sieve analysis in order to ascertain the cases of OCO-2 footprint trajectory crossing both the bloom area and adjoining bloom-free waters. The identified situations were further analyzed as case studies in order to investigate on a quantitative basis if there was any impact of $E$. huxleyi bloom areas on $\mathrm{XCO}_{2}$ registered by OCO-2. Thus, to assess the impact, $\mathrm{XCO} 2$ values registered along the OCO-2 footprint both over the bloom area and beyond it (either prior to reaching the bloom area or after leaving it) were compared. The resultant change in $\mathrm{XCO}_{2}$, i. e. $\triangle \mathrm{XCO}_{2}$, was considered as a measure of the $E$. huxleyi bloom impact on the $\mathrm{CO}_{2}$ exchange at the atmosphere-sea water interface, and hence, of the change in the $\mathrm{CO}_{2}$ atmospheric columnar content.

All case studies also included the analysis of above water surface wind force and direction over the bloom area in order to clarify the issue of air mass advection across the satellite footprint trajectory.

\section{Data sources}

Wind data. 8-day averaged satellite data from Cross-Calibrated Multi-Platform (CCMP) data http://www.rmss.com/measurements/wind/ were employed for the time period prior to 2016 (http: www.rems.com/measurements/ccmp/). CCMP gridded surface vector winds are generated through concatenation of satellite, moored buoy, 
Change of $\mathrm{XCO}_{2}$ (ppm) over E. huxleyi bloom areas in the Barents, Iceland, Greenland and North seas as recorded with the OCO-2 instrument within the time period 2015-2018

\begin{tabular}{c|c|c|c|c|c|c}
\hline $\begin{array}{c}\text { Case } \\
\text { number }\end{array}$ & Sea & $\begin{array}{c}\text { Start of 8-day } \\
\text { time interval }\end{array}$ & $\begin{array}{c}\mathrm{XCO}_{2} \\
\text { over bloom }\end{array}$ & $\begin{array}{c}\mathrm{XCO}_{2} \text { beyond } \\
\text { bloom }\end{array}$ & $\Delta \mathrm{XCO}_{2}$ & $\begin{array}{c}\text { Wind force }(\mathrm{m} / \mathrm{s}) \\
\text { and direction }\end{array}$ \\
\hline 1 & Barents & 28.07 .2015 & 393.6 & 393.0 & 0.6 & $4.6 \mathrm{E}$ \\
\hline 2 & South Iceland & 12.07 .2015 & 396.5 & 395.0 & 1.5 & $6.1 \mathrm{NNE}$ \\
\hline 3 & South Greenland & 12.07 .2015 & 397.0 & 394.0 & 3.0 & $3.0 \mathrm{WSW}$ \\
\hline 4 & South Iceland & 24.05 .2016 & 404.0 & 404.0 & 0 & $4.9 \mathrm{~S}$ \\
\hline 5 & South Iceland & 01.06 .2016 & 404.0 & 402.0 & 2.0 & $3.3 \mathrm{ESE}$ \\
\hline 6 & North & 17.05 .2018 & 410.0 & 410.0 & 0 & $4.9 \mathrm{NE}$ \\
\hline 7 & North & 18.06 .2018 & 408.0 & 407.0 & 1.0 & $8.4 \mathrm{NW}$ \\
\hline 8 & North & 26.06 .2018 & 406.0 & 406.0 & 0 & $3.1 \mathrm{~N}$ \\
\hline
\end{tabular}

and simulated wind data. Thus conjoined, these mutually harmonized data qualify as Level-3 ocean vector wind analysis product. Through the involvement of improved and extended input data, the CCMP product was updated up to the CCMP V2.0 data set that is reachable at the Remote Sensing Systems (RSS) portal. This updated data set combines RSS-7 V. 7 radiometer wind speeds, QuikSCAT and ASCAT scatterometer wind vectors, wind speed actually measured from moored buoys, and ERA-Interim wind spatial distribution simulated with the Variational Analysis Method (VAM). The resultant product is four maps at a daily temporal and $0.25^{\circ}$ spatial resolution.

In the case of the North Sea 2018, CCMP are unavailable, and in their stead ASCAT data, version 2.1 were exploited (http://www.remss.com/ missions/ascat/). To better harmonize scatterometric and radiometric wind measurements, the ASCAT data were generated with the use of a new Geophysical Model Function, C-2015.

Thus, the wind vectors that are laid upon the maps illustrating our case studies represent 8-day wind force and direction averages specifically over the areas of E. huxleyi blooms.

Atmospheric $\mathbf{C O}_{2}$ content. The column averaged dry air mole fraction, $\mathrm{XCO}_{2}$ is defined as the ratio of "the altitude-dependent $\mathrm{CO}_{2}$ number density integrated over the atmospheric column and the column abundance of dry air" [Crisp, 2015].

Having a 16-day ground-track repeat cycle, OCO-2 yields $\mathrm{XCO}_{2}$ values with single-sounding random errors in the range of $0.5-1 \mathrm{ppm}$ at solar zenith angles up to $70^{\circ}$, and at the spatial resolution of $3 \mathrm{~km}^{2}$ in nadir, i. e. $1.25 \mathrm{~km}$ in width and $\sim 2.4 \mathrm{~km}$ in length, which corresponds to a $\sim 1.8$ mrad instantaneous field of view and $3 \mathrm{~Hz}$ sampling. In 2018, the OCO-2 data processing algorithms were improved at NASA, and the current and retrospective products (L1B/L2 Version 8 and L2LiteFileVersion 9; October 10, 2018) were released (https:// docserver.gesdisc.eosdis.nasa.gov/public/project/OCO/OCO2_DUG.V9.pdf).

Only high quality data (i. e. unflagged data) were employed in our case studies. 8-day averaging of $\mathrm{XCO}_{2}$ data was implemented in this study.

E. huxleyi bloom masking. The 1998-2018 time series of E. huxley blooms in the Subarctic Atlantic and Arctic oceans was retrieved from Ocean Color Climate Change Initiative (OC CCI) data through the analysis of spectra of remote sensing reflectance, $R_{r s}(\lambda)$. The methodology is described in detail in [Kondrik et al., 2017, 2019]. Concisely, a typical $R_{r s}$ spectrum from a $E$. huxleyi bloom exhibits a maximum at $\lambda=\sim 490 \mathrm{~nm}$ at the late stage of its development, when the surface water is predominantly populated by coccoliths whereas E. huxleyi cells have already mostly died off. Accurate delineation of E. huxleyi blooms was based on fulfillment of the requirement that the spectral values of $R r s\left(\mathrm{sr}^{-1}\right)$ in the OC CCI standard spectral channels exceed the following statistically established thresholds: 0.001 at $412 \mathrm{~nm}$, 0.008 at $443 \mathrm{~nm}, 0.01$ at $490 \mathrm{~nm}, 0.008$ at $510 \mathrm{~nm}$, and $\sim 0$ at $670 \mathrm{~nm}$. On this basis, masks of $E$. huxleyi blooms were plotted for the target Subarctic and Arctic seas to restore the chronicle of spatiotemporal variations of the bloom areas between 1998 and 2018.

\section{Results and discussion}

Here we present the results of eight satellitebased case studies from the Barents, Iceland, Greenland and North seas (Table, Fig., $a-h$ ). Note that red lines show the limits of the beyond-bloom areas used in this study for assessing $\triangle \mathrm{XCO}_{2}$; black arrows indicate the force and direction of wind over the bloom area; black areas are E. huxleyi blooms.

As the Table shows, in 5 cases (The Barents, South Iceland, South Greenland, North seas) OCO-2 registered an increment of $\mathrm{XCO}_{2}$ over $E$. huxleyi bloom areas ranging between 0.6 


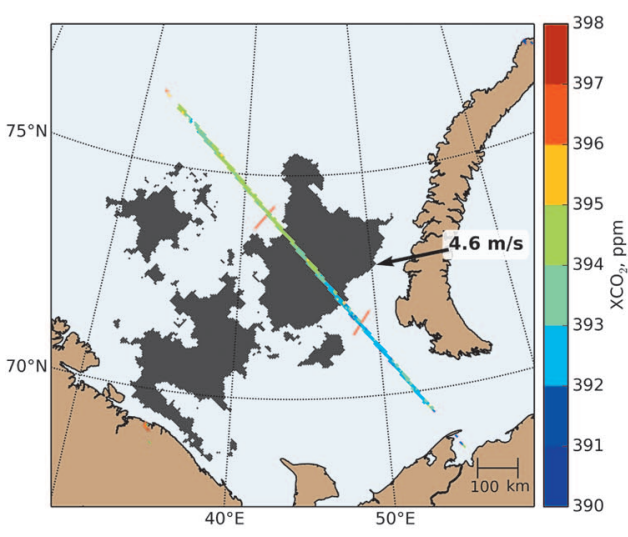

a.

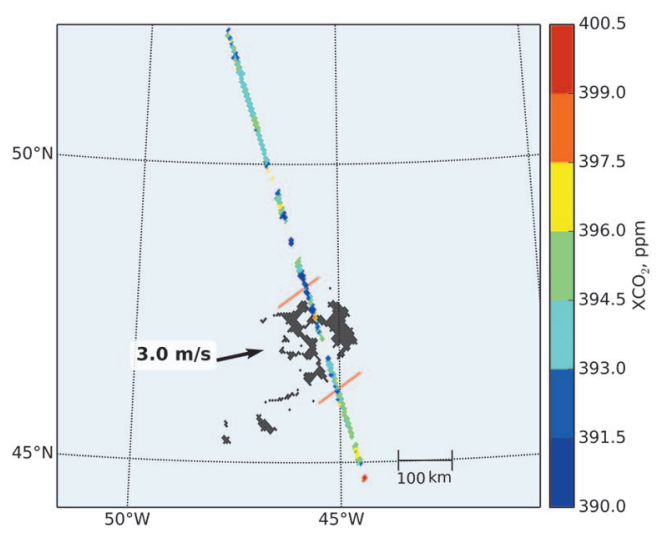

c.
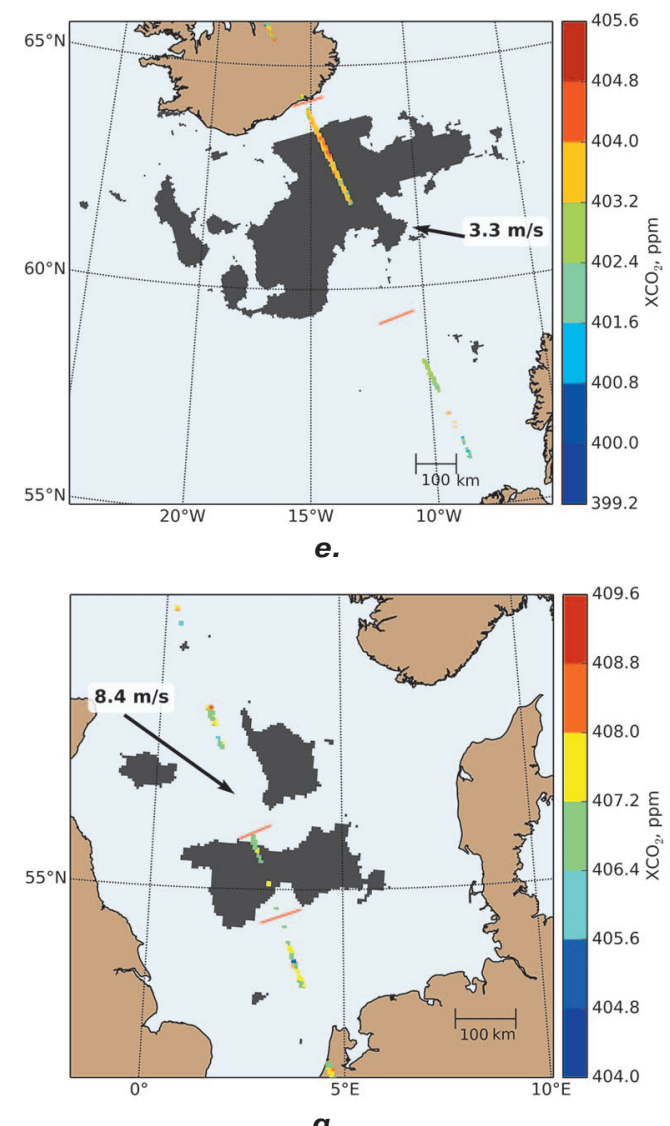

g.

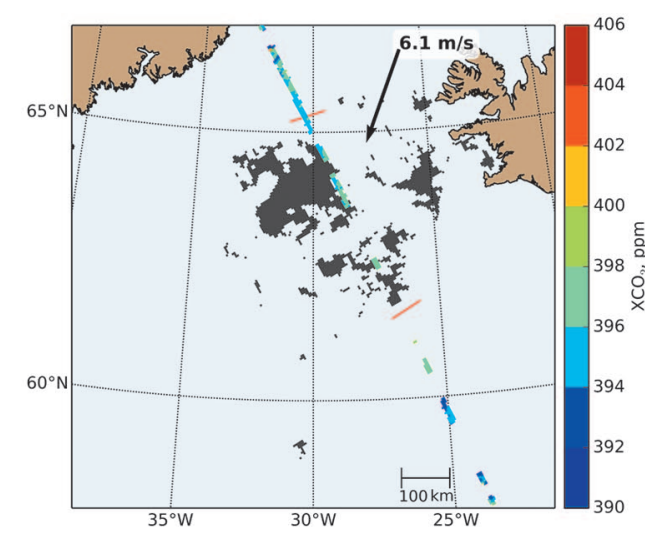

b.

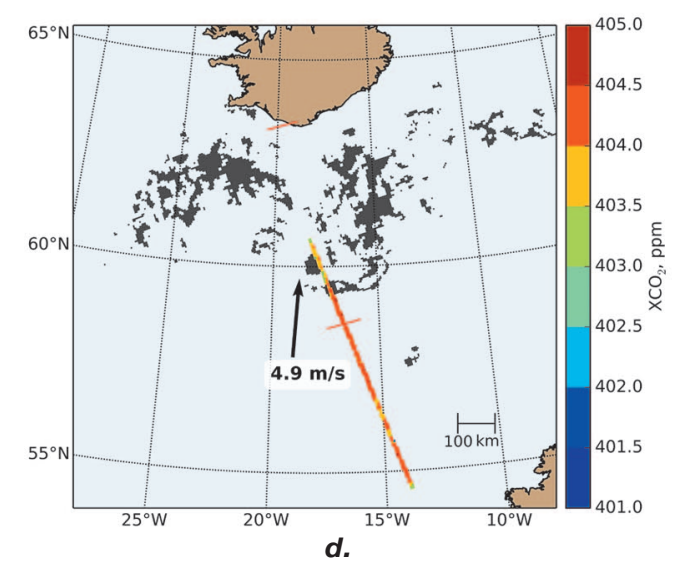

d.
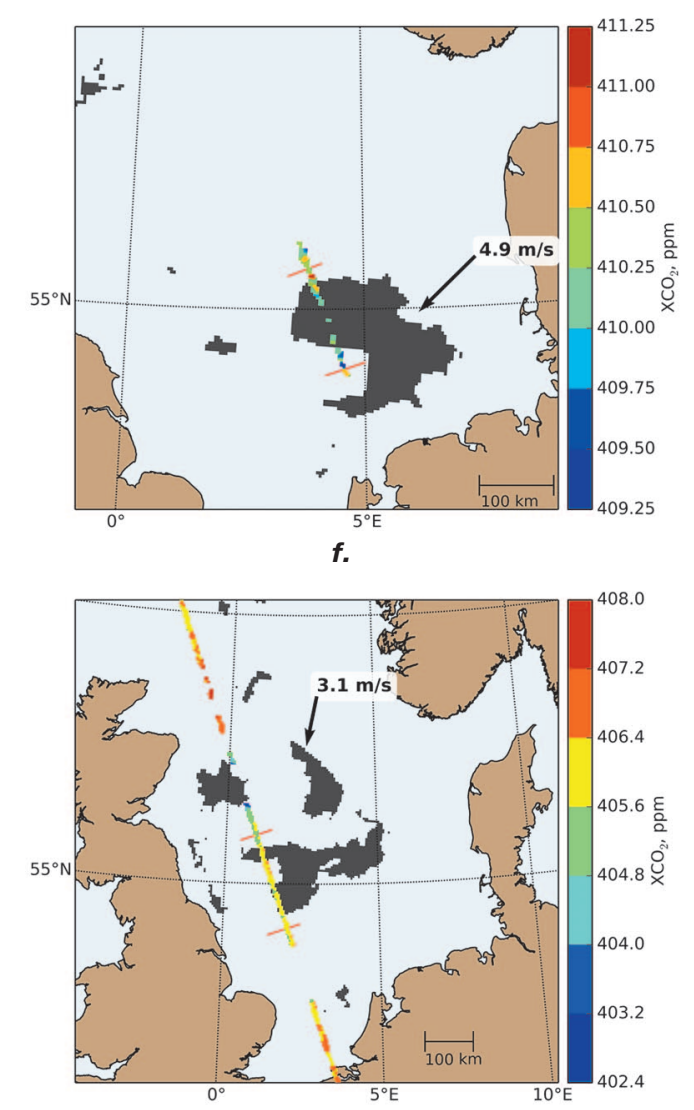

h.

OCO-2 footprint trajectory and along $\mathrm{XCO}_{2}(\mathrm{ppm})$ track values: $a-h$ are $1-8$ Cases, respectively (see Table) 
and $3.0 \mathrm{ppm}$. These numbers are fully consistent with the results we have obtained in the study of $E$. huxleyi -induced $\mathrm{XCO}_{2}$ in the Black Sea as registered in 2016-2017.

However, in three cases (the South Iceland, and North seas), no $\mathrm{XCO}_{2}$ enhancement was found. A combined OCO-2 and wind data analysis has shown that the explanation of the apparent absence of $E$. huxleyi blooming impact upon $\mathrm{XCO}_{2}$ might reside in the effect of above water air mass advection. Indeed, for cases 4,6 , and 8 the meteorological and E. huxleyi blooming conditions were specific. In case 4 the blooming area was essentially inhomogeneous/fractionized, and the wind direction was southern, i. e. bringing air masses from the parts of the sea free of any $E$. huxleyi bloom influence.

In case 8 there were very similar conditions in terms of wind-driven advection of above-water air from marine tracts void of E. huxleyi blooming. It is also worth mentioning that the blooming area was also significantly fractionized.

A special consideration should be given to case 6. At first glance, it appears that the E. huxleyi-driven $\triangle \mathrm{XCO}_{2}$ signal should not be zero: the footprint trajectory traverses the bloom area, and the advected air comes from a large portion of bloom. However, the number of OCO-2 pixels within the bloom area is rather small, rendering the $\triangle \mathrm{XCO}_{2}$ retrievals insufficiently reliable.

\section{Concluding remarks}

Produced in the reaction of calcification inside the cell of E. huxleyi, $\mathrm{CO}_{2}$ becomes available for the reaction of photosynthesis with a result of a reduced uptake of dissolved $\mathrm{CO}_{2}$ from ambient water. Thus, surface marine waters within the bloom of $E$. huxleyi turn out to be less $\mathrm{CO}_{2}$ depleted. Moreover, the thus enhanced partial pressure of dissolved $\mathrm{CO}_{2}$ can either nullify the flux of atmospheric $\mathrm{CO}_{2}$ or even reverse it. This has been proven in shipborne surveys, and through spaceborne observations over the Black Sea: the enhancement of $\mathrm{CO}_{2}$ content in the atmospheric column proved to be within 1-2 ppm.

The eight case studies conducted with the employment of OCO-2 satellite data and presented in this concise report have shown that the impact of $E$. huxleyi blooming phenomenon on the atmospheric $\mathrm{CO}_{2}$ partial pressure over the North, Iceland, Greenland, and Barents seas proved to be of the same order of magnitude as over the Black Sea $(0.6-3 \mathrm{ppm})$. It is also shown that the magnitude of $\mathrm{CO}_{2}$ enhancement in the atmospheric column is significantly controlled by the air advection in the boundary layer.
Arguably, this might be an indication of some inherent property of E. huxleyi, and the obtained results on the increment of $\mathrm{CO}_{2}$ in the atmospheric column over the blooms of this alga can be considered as representative of this phenomenon across the oceanic tracts, at least, in the Northern Hemisphere.

We express our gratitude for the financial support of this study provided by the Russian Science Foundation (RSF) under the project number 17-17-01117.

\section{References}

Balch W. M., Drapeau D. T., Bowler B. C., Lyczkowski E. R., Lubelczyk L. C., Painter S. C., Poulton A. J. Surface biological, chemical, and optical properties of the Patagonian Shelf coccolithophore bloom, the brightest waters of the Great Calcite Belt. Limnology and Oceanography. 2014. Vol. 59. P. 1715-1732. doi: 10.4319/lo.2014.59.5.1715

Crisp D. Measuring atmospheric carbon dioxide from space with the Orbiting Carbon Observatory-2 (OCO-2). Proceedings of SPIE. Earth Observing Systems XX, 960702(8 September 2015). 2015. Vol. 9607. doi: $10.1117 / 12.2187291$

Holligan P. M., Fernández E., Aiken J., Balch W. M., Boyd P., Burkill P. H., Van der Wal P. A biogeochemical study of the coccolithophore, Emiliania huxleyi, in the North Atlantic. Global Biogeochemical Cycles. 1993. Vol. 7, no. 4. P. 879-900. doi: 10.1029/93GB01731

IPCC. Climate Change 2014: Synthesis Report. Contribution of Working Groups I, II and III to the Fifth Assessment Report of the Intergovernmental Panel on Climate Change. Core Writing Team, Pachauri R. K., Meyer L. A. (Eds.). IPCC. Geneva, Switzerlan, 2014. P. 151.

Kondrik D. V., Kazakov E., Chepikova S., Pozdnyakov D. V. Prioritization of physical factors controlling Emiliania huxleyi blooms in subarctic and arctic seas: a multidimensional statistical approach. Biogeosciences. 2019 (submitted).

Kondrik D. V., Pozdnyakov D. V., Johannessen O. M. Satellite evidence that $E$. huxleyi phytoplankton blooms weaken marine carbon sinks. Geophysical Research Letters. 2018. Vol. 45, no. 2. P. 846-854. doi: 10.1002/2017GL076240.

Kondrik D. V., PozdnyakovD. V., Pettersson L. H. Particulate inorganic carbon production within E. huxleyi blooms in subpolar and polar seas: a satellite time series study (1998-2013). Int. J. Remote Sens. 2017. Vol. 38(22). P. 6179-6205. doi: 10.1080/01431161.2017.1350304

Moore T., Dowel M. D., Franz B. A. Detection of coccolithophore blooms in ocean color imagery: A generalized approach for use with multiple sensors. Remote Sensing of Environment. 2012. Vol. 117. P. 249-263. doi: 10.1016/j.rse.2011.10.001

Sathyendranath S., Krasemann $\mathrm{H}$. Climate Assessment Report: Ocean Colour Climate Change Initiative (OCCCI) - Phase One. Technical Report, ESA OC-CCI. 2014. 
URL: http://www.esa-oceancolour-cci.org/?q=documents (accessed: 05.02.2019)

Selyuzhenok V., Kondrik D., Kazakov E., Pozdnyakov $D$. Bering Sea: A possible explanation to the extraordinary bloom outburst of E. huxleyi in the late 1990s early 2000s. Remote Sensing Letters. 2019 (submitted).

Shutler J. D., Land P. E., Brown C. W., Findlay H. S., Donlon C. J., Medland M., Snooke R., Blackford J. C. Coccolithophore surface distributions in the North Atlantic and their modulation of the air-sea flux of $\mathrm{CO}_{2}$ from 10 years of satellite Earth observation data. Biogeosci-

\section{СВЕДЕНИЯ ОБ АВТОРАХ:}

\section{Морозов Евгений Андреевич}

старший научный сотрудник

Научный фонд «Международный центр по окружающей среде и дистанционному зондированию имени Нансена» 14-я линия В. О., 7, оф. 49, Санкт-Петербург, Россия, 199034

эл. почта: evgeny.morozov@niersc.spb.ru

\section{Кондрик Дмитрий Вячеславович}

научный сотрудник

Научный фонд «Международный центр по окружающей среде и дистанционному зондированию имени Нансена» 14-я линия В. О., 7, оф. 49, Санкт-Петербург, Россия, 199034

эл. почта: dmitry.kondrik@niersc.spb.ru

\section{Чепикова Светлана Сергеевна}

младший научный сотрудник

Научный фонд «Международный центр по окружающей среде и дистанционному зондированию имени Нансена» 14-я линия В. О., 7, оф. 49, Санкт-Петербург, Россия, 199034

эл. почта: sveta.chepikova@niersc.spb.ru

\section{Поздняков Дмитрий Викторович}

заместитель директора по науке, руководитель группы водных экосистем, д. ф.-м. н., проф.

Научный фонд «Международный центр по окружающей среде и дистанционному зондированию имени Нансена» 14-я линия В. О., 7, оф. 49, Санкт-Петербург, Россия, 199034

эл. почта: dmitry.pozdnyakov@niersc.spb.ru ences. 2013. Vol. 10. P. 2699-2709. doi: 10.5194/bg10-2699-2013

Thierstein H., Young J. Coccolithophores: from molecular processes to global impact. Berlin: Springer, 2013. $565 \mathrm{p}$.

Westbroek P. E., De Vrind-De Jong W., Van der Wal P., Borman A. H., De Vrind J. P. M. Biopolymer-mediated calcium and manganese accumulations and biomineralization. Geologieen Mijnbouw. 1985. Vol. 64. P. 5-15.

Received February 05, 2019

\section{CONTRIBUTORS:}

\section{Morozov, Evgenii}

Scientific foundation "Nansen International Environmental and Remote Sensing Centre"

$14^{\text {th }}$ Line, 7, Office 49, Vasilievsky Island, 199034

St. Petersburg, Russia

e-mail: evgeny.morozov@niersc.spb.ru

\section{Kondrik, Dmitrii}

Scientific foundation "Nansen International Environmental and Remote Sensing Centre"

$14^{\text {th }}$ Line, 7, Office 49, Vasilievsky Island, 199034

St. Petersburg, Russia

e-mail: dmitry.kondrik@niersc.spb.ru

\section{Chepikova, Svetlana}

Scientific foundation "Nansen International Environmental and Remote Sensing Centre"

$14^{\text {th }}$ Line, 7, Office 49, Vasilievsky Island, 199034

St. Petersburg, Russia

e-mail: sveta.chepikova@niersc.spb.ru

\section{Pozdnyakov, Dmitry}

Scientific foundation "Nansen International Environmental and Remote Sensing Centre"

$14^{\text {th }}$ Line, 7 , Office 49 , Vasilievsky Island, 199034

St. Petersburg, Russia

e-mail: dmitry.pozdnyakov@niersc.spb.ru 